\title{
SEEKING BORDERS AND THEIR MYTHOLOGY IN WESTERN THRACE, GREECE
}

\author{
Evangelos Avdikos
}

\begin{abstract}
This article deals with the boundaries of western Thrace, a Greek region bordering both the Bulgarian (northern) and Turkish (eastern) Thrace. The main aim here is to re-contextualise the perspective of the residents of western Thrace on Thracian borders. Such an interpretive process has to take account of the political changes in the southern part of the Balkan Peninsula after the collapse of the communist regime in Bulgaria and the increasing incorporation of Greece into the political structures of the European Union.
\end{abstract}

Keywords: border, Bulgaria, European Union, Greece, identity, liminality, migration, Pomaks, Turkey

The aim of this article is to explore the function of the border of western Thrace, the furthest and easterly area of Greece, which, in the east, shares a border with Turkey. Specifically, Greek (eastern) Thrace is a part of the historic and geographical area of Thrace which today consists of two other parts belonging to Bulgaria (northern Thrace) and Turkey (eastern Thrace). What changes occurred in the perception of the border over the 20th century? What was the role of older narrative motifs in the representation of the border? And what is the situation at the beginning of the 21st century, assuming that Greek borders are also the borders of the European Union? How - and to what extent - is the geographical border related to the invisible borders between the ethnic groups of the Muslim minority, on the one hand, and between the Christian and the Muslim population on the other hand.

\section{THE THEORETICAL FRAMEWORK}

This paper makes use of autoethnography, which has been of great value in the process of revealing the importance of subjectivity. "Autoethnography is a qualitative research method that utilizes data about self and its context to gain an understanding of the connectivity between self and others within the 
same context" (Ngunjiri \& Hernandez \& Chang 2010: 2). Autoethnography borrows the theoretical reflections of anthropological thought, with the aim of overcoming misgivings about feelings and an obsession with generalisability; that is, the researcher is attempting to find a balance between him/herself and the other. This theoretical and methodological framework facilitated my fieldwork and relations with my informants. My academic presence in Thrace over a long period of time (Narayan 1993: 671-686) and my public intervention created a framework for communication, which eased the transition from private to public discourse. My research in Thrace formed a part of my academic autobiography. This created a favourable atmosphere for discussions with my numerous informants, who were both ordinary citizens and members of the intellectual, financial, and social elite.

I was led to consider whether private conversations on all these matters are in fact representations of otherness and ethnic boundaries disseminated through public networks or whether such private conversations rest on ideas and motifs deeply rooted in a previous historical environment (Brunnbauer 1999: 40). Let me give an example. "You do not live in the area yet. Thrace has changed. Swarms of immigrants come down from the northern Evros." These phrases were uttered by a close friend in Alexandroupolis, in Greece. She is not politically conservative and is indeed an open-minded person, radical, and opposed to any nationalistic perceptions of otherness. Could we attribute the content of a private conversation about migrants and boundaries exclusively to the influence exercised by public discourse? Is history, when made in the present, not engaged in conversation with the past? Such an ahistorical position cannot be maintained. Thus I think it useful for my approach to attempt to trace motifs in private narratives that cause people to easily accept ideas and perceptions regarding otherness and its symbols (Linke 1990: 118). "I am afraid that I will not take pleasure in my house. Some Turks have been living in it," added the abovementioned colleague.

Is such a perception an exception? It most certainly is not. In these cases the use of both long-term research and researcher autobiography is unavoidable. Eight years (1992-2000) of teaching and research presence in the Evros area, which gave me a chance to conduct fieldwork in various localities in this region and to have conversations with many inhabitants, mainly in the context of daily life outside my research, in places across the Evros prefecture, contributed to the understanding of the historical, cultural, and social context of Thrace by me as an investigator from the outside. However, it also facilitated my identifying with the inhabitants of Thrace, with the result that they more or less regarded me as a local. The fact that I had, then, to transmute from an external to an 
internal observer, and also move in the opposite direction, which was achieved through reflexivity, contributed to a fuller understanding of many perceptions held by local people, relating to such concepts as boundary, ethnic/national otherness, and cultural practices. Thus I am convinced that this scepticism is not a limited phenomenon.

\section{Narrative Representations before the Second World War}

What occurred in the Balkans after the communist regimes collapsed forms an appropriate framework for contextualising the narrative on boundaries in Thrace. All these ethnic clashes called into question a very strict dipole relating to the stereotype of continuity that has been identified with the nation-state. Boundary as a concept has been ingrained in human minds and practices since the distant past and obviously before the nation-state emerged. Borders are usually considered state boundaries. However, they form a symbolic expression of every form of power and of ethnic groups that have felt a need to form distinctions (Gielis 2009: 599; Van Houtum 2005: 672-679). The example offered by the Balkans is very useful for grasping the idea of a boundary as a pre-national motif, which is then infused into various cultural forms that are reinvented in pursuit of national demands (Strüver 2003: 166-167; Görög-Karady 1992: 114-126).

Clearly, the only way to untangle this is to go back to the matter of how history is transformed into a mythology that contains the nuclei of historical facts now located in another historical, social, and political environment (Herzfeld 1989 [1987]: 123-149). This means that we need, in the case of western Thrace, to examine how the border of Thrace is linked with events both historical and re-invented. The first independent Greek nation-state was created in 1830. The border with Turkey was fixed by the Treaty of Lausanne in 1923, whereby the state of Turkey was established, replacing the Ottoman Empire that had existed here for about four hundred years.

This is the problem behind the discussion on the future of property in the Evros area and the dam, the so-called frachtis. Is there any interrelationship between these two issues? At first sight it may seem possible to connect one with the other. However, history - or its representations - and narratives can show that such an interrelationship is not bizarre. Various narrative forms are imbued with otherness expressed in large numbers. In particular, boundaryrelated narratives are organised around the border and how it creates the relationship of the self to the other (Paredes 1995 [1993]: 19-48). 
Let us take an example. In some erotic songs, the whole idea revolves around a potential marriage between a Greek girl and a Turkish man (Avdikos 2007: 104-121). The girl's mother focuses on how rich the Turk is and on the fact that if the daughter marries him, she will ensure her wellbeing. However, the girl disagrees with her mother and considers a range of ways to escape this marriage. All such songs display an ambiguous attitude towards Turkish otherness. On the one hand, there emerges a tendency towards co-existence, if not towards a blurring of ethnic borders, and on the other hand, songs express insistence on a strict representation of a line defining ethnicity.

This conflict, it should be noted, is not static and unchanging over time. It depends on the historic environment. Thus the defining line between Greece and Turkey, especially since the integration of the Evros area into the Greek nation-state in 1919, did not originally depict a conflicting representation in both public and private discourses. The Greek-Turkish border clearly demarcated the eastern end of Greek territory from 1920 onwards, after the signing of the Treaty of Sévres (Akçam 2004). However, in daily life, the River Evros did not actually function as a strict boundary on either bank. Many Greeks faced difficulties because they had resisted the German-Bulgarian occupation (1941-1944) and were forced to escape from Greece and seek refuge in Turkey. Furthermore, during the 1950s and 1960s residents on both sides co-operated over fishing and hunting (Avdikos 1998: 262). For locals, the border was not a barrier.

\section{The Cold War Narratives}

It is difficult, anyway, for the border to tell the same story. "This means that the perceptions of borders differ when they focus on different parts of the border" (Laube \& Roos 2010: 32). In western Thrace the border is to be regarded in a context of various stories that show the different historical past and the quality of relations with bordering peoples.

As regards Turkey, these narratives illustrate the historical and political relations between the two states (Rizas 2009: 367-387) that were political allies, in that both countries belong to NATO. They thus belonged to the camp of the West, in contrast to Bulgaria, which belonged to the opposing camp. To a great extent, the Greek-Turkish border was constituted by the River Evros, which separated the western, that is, the part that belonged to Greece, from the eastern Thrace, which had been granted to Turkey. There were certainly close relationships between inhabitants on either side of the border and the two states developed friendly relations after the Ankara Convention of 1930 
(Demirözü 2008: 313-314). Many Greeks who lived on the Greek bank of the River Evros were refugees from the opposite side (today the European or eastern Thrace). The same was the case with many inhabitants on the Turkish side of the river. Thus the inhabitants shared a common feeling of nostalgia for the ancestral land that they had been compelled to leave (Stuckey 2009: 14). They also shared common memories.

However, the situation radically changed after the so-called Septemvriana (September Events) in 1955 (Zayas 2007: 137-138; Alexandris 1992). ${ }^{1}$ The occasion for this orchestrated uprising in 1955 on the part of the inhabitants of Constantinople was a false rumour that Greeks had set fire to the house in Thessaloniki in which Kemal Ataturk, the founder of the modern Turkish state, had been born. The houses and property of the Greeks of Constantinople were destroyed. This led to mass migration to Greece and the drastic reduction in size of the Greek minority (Vryonis 2005). These events directly influenced the functioning of the border. The Evros area began to show a dangerous level of pollution, which caused the cessation of communication and collaboration in fishing and hunting. Both sides of the border turned their backs on each other, turning in upon themselves. Matters deteriorated yet further after the Turkish invasion of Cyprus in 1974, which made the border even more 'polluted' and dangerous. Thus Thrace and the Evros area became a military camp. Indicative of this is the fact that the Greek-Turkish border acquired a negative symbolism. For a long period it had been a place of exile and national exclusion for citizens with political views that put them among the 'tainted' in the Cold War (Tsibiridou 2005: 66), thanks to the Civil War, or those exiled there may have committed some administrative offence and fallen into disfavour in the eyes of their superiors in the civil service. The threat that public servants of the Greek state faced was that of social stigmatisation and geographical isolation, that is, what has been termed 'spatial strategy' (Certeau 1980).

Keep silent, Lady Virgin. Again with the years and time, it will be ours. (Ioannou 1977: 91)

Oral literature provides a motif, albeit in inverted form. Both the Agia Sofia song ${ }^{2}$ and the perception of the future of Greek Thrace are based on a historical substratum resting on an eschatological view of history (Andriomenos 2011: 24-27). The analysis that anthropologist Michael Herzfeld has performed on the song is particularly successful (Herzfeld 1986: 124-139). He devotes the sixth chapter (Expansion and Collapse) of his study to the song. He also maintains that there is an eschatological concept of history that led many to avoid active support to the struggle for national independence. Herzfeld agrees with Politis (1918: 151-170), the founder of Greek folklore, that this song embodies 
various prophecies according to which the last emperor, turned to marble, will return and enter Constantinople in triumph. Herzfeld also agrees with Politis that such prophecies fed the expectation of liberation. Herzfeld, however, differs from Politis as regards the former's view that this motif is an indication of cultural continuity. In any case, the last verse was a main source of hope for the renaissance of Hellenism.

In other words, such a discourse is conditioned by a determinist outlook. Thus the territory and borders merely constitute a temporary situation before eschatology is redeemed. This view is directly related to the historical relations between Greeks and Turks in the context of the Ottoman Empire that formed the stereotypes of otherness, and "the threatening Turk" (Hirschon 2008: 88), who, in an abstract fashion, in a private discourse, is regarded as a source of unending enmity and as the "other of Greeks" (Theodossopoulos 2006: 3). The various forms of both the spoken discourse, such as riddles, proverbs and songs, and of the private discourse have created the figure of the Turk as a barbarian, a harsh and bloodthirsty conqueror. This image of the Turk finally became clear and definite with the Treaty of Lausanne. Thrace gradually became a volatile region, thanks to the institutionalisation of a three-way pattern of conflict. In this were caught up the Muslim minority, Greece as the state in which the minority was resident, and Turkey as an external national entity that was guarantor of the safety of its co-religionist minority. The Treaty of Lausanne gave Turkey the power to intervene in anything regarding relations between the Greek state and the minority, whenever they thought they were capable of exercising pressure. Thus the border functions as a mirror of the state of the Greek-Turkish relations.

The stereotype of the 'evil Turk' forms the historical and cultural background that favours Greeks' reformulation of images of Turks and vice versa. Some skeletons from the past have come out of the cupboard, with important consequences for the process of restating them and for their passage into a different context. Particularly after the Septemvriana and the invasion of Cyprus by Turkey in 1974, relations between Greece and Turkey worsened and Greeks and Turks do live in a state of national introversion and isolation, as regards their supposedly recalcitrant neighbour. National frontiers, particularly during the seven-year period of military dictatorship in Greece, between 1967 and 1974, are endowed with a symbolism of suspicion and hostility and are responsible for a 'victim complex' (Hirschon 2008: 87). In particular, the Greek-Turkish border on the River Evros has become the symbol of the 'danger from the East' (Troumbeta 2001: 50), a belief that is responsible for the formation of a feeling of fluidity on the spatial formulation of the frontiers. This atmosphere has contributed to the creation of what Ardener (1989: 69) has called a 'hollow category'. The 
conception of the Turk is formed through discrimination and prejudice that spring from various sources in the main national fears and suspicions.

All this is intimately associated with the process whereby the Greek nationstate was formed. It was created upon the independence of territories from the Ottoman Empire. The borders on the River Evros were the expression of the Sevres Treaty (10 August 1920), when Thrace was absorbed into Greece, the demonised Other, which, at least in the eyes of Greek public discourse, did not allow the question of borders in the area to be settled once and for good. The danger from the East that created the feeling that all was temporary on the borders led the whole of Thrace to a state of social and economic asphyxiation (Troumbeta 2001: 51), a fact that rendered the minority invisible for a lengthy period ending in the 1980s. State authorities remained indifferent, although they did not hinder the solution of the problems of the minority, such as housing and ownership. This was a period when, inter alia, the minority and thus also Turkey were portrayed as the expression of a dark and stigmatised past and culture of the East, which the Greeks wish to forget. It is a culture with which the Greeks feel uncomfortable, as it is identified with the 'backward Orient', whilst, as early as the 1960s, attempts were being made to complete the westernisation that has been a dream and a goal since the Greek War of Independence in the early 19 th century.

In addition to this view, yet another one of the area has come into existence since the early 1960s, when Greece became a member of the then European Community. As a result, the Evros authorities placed signs just inside the Greek border, for visitors coming from Turkey as they left the customs post at Kipi. These signs reminded the visitor that Alexandroupolis, the capital of the Evros area, was the first city in Europe that they would encounter. In general, after the Second World War, the River Evros became a symbol that distinguished citizens of Europe from the people who lived beyond the eastern bank of the river. Such people were regarded as oriental. As my informants said, this meant that people of the western bank, that is, Greeks, identified with progress. They feel that the Evros border separates two different worlds.

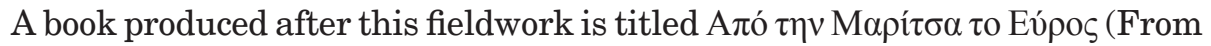
Maritsa to Evros; Avdikos 1998: 266). Maritsa (sometimes also called Martsa) is the Slavic name for the River Evros, which became the official name of the river immediately after the liberation and integration of western Thrace into the Greek state, on 14 May 1920. The Slavic name Maritsa, however, continued to be used in private discourse by those resident along the river. The Greek name Evros unofficially replaced the Slavic name in the first decades of the post-war period. For locals, however, the river remained the River Maritsa, a thread of cultural continuity that echoes the multicultural and multiethnic 
co-existence in this area as reflected in place-names. There are two important factors in regard to how the river was viewed up to the late 20th century. Firstly, Evros, the name employed in official discourse, is increasingly penetrating the unofficial speech of young generations, thanks to the effects of the educational system. Thus, in particular after the Septemvriana in Istanbul and the invasion by Turkish troops of Cyprus, it became the emblematic outpost of the territory of the Greek state. The name Maritsa, on the other hand, conveys the memory of a world and culture that have faded away.

In Levi-Strauss's view (1966: 181), "the name is an identifying mark". If we use this term and apply it to a political system, in this case to the process of creating the Greek nation-state, the change of name replaces, at a symbolic level, the historical and cultural continuity of the ethnos, which was interrupted by the Ottoman Empire. There is, nevertheless, yet another level to the discussion, which is to be linked with the change of political environment, with the move from the Ottoman Empire made up of many nations to a developing and homogenised nation-state that endeavoured to gain control from the start at the symbolic level of names and territorial domination. The change of name was expressive of a desire for communication, but was chiefly an act whereby power relations were made manifest (Cohen 1974: 16). So if we distinguish between private and public ways regarding the interpretation of symbols, then this theoretical framework facilitates the understanding of private and public discourses that are produced in Greece, pertaining to the name of the river and, more broadly, in relation to the orientation of the Greek state. In other words, we can understand that the nation-state built in Greece is organised around a contradictory principle. On the one hand, there is the orientation towards the West and the attempt to apply the principles of the Enlightenment to the organisation of the state. On the other hand, there is the inheritance of the Orient, experience arising from co-existence with many other ethnic groups. ${ }^{3}$ The Greek name Evros expresses, at a symbolic level, the intention of the Greek state to cut loose from the Ottoman and multicultural past.

\section{TRANSNATIONAL MIGRATION, EUROPEAN UNION, AND BORDERS}

The 1990s were of crucial importance in dictating how the borders of Thrace functioned and how they influenced the invisible borders between the majority community of Christians and the Muslim minority in Thrace. Since then, Greece has become more closely linked to the political structures of the European Union, a process which has had various consequences. The "internalisation of 
minority rights gained significant momentum towards the end of the twentieth century" (Memisoglu 2007). In the case of Greece, this was expressed in the form of various pressures on Greece to apply the measures passed by the European Union regarding the rights of members of the community as citizens of the Greek state.

Unavoidably, the Muslim minority in Greece is studied in the context laid down by international law regarding the rights of minorities, Greek-Turkish relations, and the relations that have developed within the Muslim minority. All these three factors negotiate visible and invisible boundaries. That is to say, they are influenced by the relations between Greece and Turkey and the views evolved regarding the Greek-Turkish border. They are also influenced by the legal decisions and political texts produced by the European Union (Tsitselikis \& Christopoulos 1997).

Public discourse has thus gradually incorporated European discourse and representations of a wide range of matters relating to how the Greek state functions. The European Union functions as a supra-national entity that reformulates relations within its nation-states. In the case of borders between Greece and Turkey, in western Thrace, this can be seen in the sign placed at the customs Post At Kipi, the main gateway from Turkey to Greece, reading, "Greece, the First Country towards the European Union". This slogan expressed both private and public discourses in the area. The borders between Greece and Turkey thus lay down hierarchies of national states. ${ }^{4}$

Greece, then, is adapting itself at a fairly speedy pace to the status quo laid down by the European Union, whilst at the same time Thrace is turning into a testing ground for multiculturalism, a new concept imported by the former (Tsibiridou 2009). As part of this, the existence of two conflicting concepts is to be noticed. On the one hand, there are the attempts on the part of the Muslim community to claim equality in the context of the nation-state of Greece and to protect its rights regarding education established by the Treaty of Lausanne. The Federation of Western Thrace Turks in Europe has been playing a leading role in this direction. Their aim is to institute bilingual education at nursery school level, but they also adhere to their right to define themselves as Turks. All this forms a uniform Muslim identity, which, however, has gradually come to be regarded as Turkish.

On the other hand, there is the doubt cast on the idea that Muslim and Turkish identities are one and the same. The Greek state and the municipality of Komotini support this opening for multiculturalism and have instituted a 'food event'. The theoretical approach employed by Yiakoumaki in her doctoral dissertation is remarkable. The relationship between Greece and the European Union reinforces positive feelings on the part of the Greeks. Such sentiments 
stand in opposition to Herzfeld's cultural intimacy. Yiakoumaki (2003: 105) defines this new view held by Greeks as 'cultural autarky', that is, a trope in nationalist discourse, which through the affirmation of cultural 'possession' becomes a powerful affirmation of national existence.

All these new concepts have consequently flowed into the perception of the Greek-Turkish border. However, this process is ill-focussed and tends to the regressive, depending on the current status of relationships between Greece and Turkey. In addition, the meaning borne by the border is connected with some other, mainly economic factors. This was made clear by the events in the northern part of the Evros region in 1990. At that time most of the inhabitants would go across the border at the village of Kastanies, in the northern part of the region, to do their shopping in Adrianoupolis (Edirne). This deprived local shops of income vital to their survival. The situation raised the question as to how the border functioned and whether it in fact protected Greeks' interests. Inevitably, this public discussion drew on a pre-existing view of the border, infused with particular local meanings.

Clearly, themes relating to representations of the border are perplexing and contradictory. Some Greek citizens pride themselves on holding European citizenship, a feature, in their opinion, which automatically makes them superior to those who live beyond the eastern bank of the River Evros. Such persons managed for some years to convince authorities to impose control on the Greek citizens passing through the Kastanies customs post to enter Turkey. It must also be said that those making such demands stress the risk of economic decline in the northern Evros region, because of uncontrolled access to Turkey and because of the subsequent flow of capital into the Edirne (Adrianoupolis) market (Prokkola 2008: 658).

It is clear that, when the border is endowed with such meanings, the concept has moved away from its original sense. The meaning now assigned to the border does not draw attention to a traditional representation of the border as an indicator of national territory. Our example above throws light on a new perception of the border, which is now considered to demarcate an economic zone necessary for the survival of a community. This conception of the border, although it indeed dominates the discourse, has never actually moved into the foreground.

In my view, this concept of the border has caused all the current public discourse over the frachtis over recent months to cohere. What differentiates it from the previously prevailing conception is how the concept of liminal space is used. The residents of the northern Evros region regard the area as liminal (Turner 1967: 93-100) and thus exposed to the danger of losing its economic well-being, which may prove disadvantageous for the Greek-Turkish border 
balance. Later, as part of a wider discussion on the European perspective of Turkey, the liminality was expanded to include all of Thrace. This was now regarded as facing the danger of inundation by Muslims from Turkey, a situation capable of changing the composition of the population. There is a permanent and unchanging thread that runs through all similar narratives on the border liminality. It is often interconnected with what happens on the eastern bank of the River Evros. The existence of the border guarantees the safety of liminal space ${ }^{5}$. Thus strict surveillance of borders is regarded as a necessary condition both for maintaining the current ethnic composition of the population and, therefore, for maintaining the territorial integrity of the Greek state. Furthermore, the prospect of the free movement of labour from Turkey to Greece supplied material for private and public discourses over the decade 2000-2010, when Turkey was seeking entrance to the European Union. This possibility was regarded as a threat to the economy both of the area and of Greece as a whole, since it was thought that it would trigger seasonal transnational migration of cheap labour from Turkey to Greece, which would lead to Greeks' unemployment and the closure of Greek businesses.

In early 2011, this discussion moved from being a peripheral issue to becoming a matter for national debate. Immigrants, mainly from Asia and Africa, were entering Greece via the land section of the Greek-Turkish border in the northern Evros region, a fact that set off a public debate on law and order, migration, unemployment, the ethnic composition of the Greek population, and, above all, on the concept of the nation-state. Despite the importance of this, I intend to remain focussed on how the border is linked to the concept of liminal space. So in the case of illegal immigrants (lathrometanastes being the term used in Greek public discourse, despite the disapproval of some of the participants in this discussion), liminality is transmitted to southern Greece.

It is interesting that the majority of Greeks, despite being adherents of a wide range of political parties, considered that the dam, the frachtis, was necessary, in order to avoid the expansion of liminal space in nationwide terms. The crucial point in the maintenance of this attitude was the involvement of the European Union in the whole process, a fact that mitigated the national burden of guilt by shifting the responsibility for the entire issue to the European agenda.

The matter of the borders is to be set in a broader context. An increasingly large number of migrants from the countries of Asia and Africa, suffering from serious financial and political problems, are seeking a way out in Western Europe from hunger and the danger of genocide. They attempt to reach Europe via Greece, the first country of the European Union on their way.

Transnational migration has given a new meaning to the borders between Greece and illegal immigrants who cross either the land section of the Greek- 
Turkish border or the River Evros. This flow of migrants from the Evros area has made the matter of transnational migration a basic problem for Greece, with tensions increasing in the wake of the economic crisis in Greece in 2010. The increasing influence of illegal migrants and the inability of the Greek state to handle the matter in a humane fashion and safely for all have led to the strengthening of extreme rightwing views and spread of racist ideas. This has occasionally been attributed to Turkey, due to the suspicion that has been cultivated that Turkey is responsible for increasing the flow of illegal migrants to Greece, in order to dispose of them.

The Greek-Turkish borders on the Evros, and the inability of Greece to prevent migrants from crossing the borders have become the symbols of a 'conspiracy'. This motif repeats what both the private discourse and the narrative discourse of folk culture have expressed in the past regarding the danger and certainty that Thrace will fall into the hands of Turkey.

\section{GREEK-TURKISH BORDERS AND INVISIBLE BORDERS IN THRACE}

Another dimension to the question of how borders are defined lies in the question of how national borders are associated with ethnic borders, the so-called 'invisible' borders. The ambiguity that arises from this acquired a new lease of life at the end of the 20th and in the early years of the 21st century. For Greece, during this period it was a political priority to deepen and reinforce its position within the European Union. This, however, had various, and inconsistent, impacts on how boundaries are represented. In other words, the increasing integration of Greece into the European Union led to the questioning of the inflexible manner in which, at a national level, both visible, national, and invisible, ethnic, boundaries were comprehended (Fisher Onar \& Özgüneş 2010: 122-123). The old world had collapsed and international relationships had completely changed. During this period, the European Union focused clearly and powerfully on human rights, on the rights of minorities, and on religious freedom (Pollis 1992: 177). This led to the redefinition of the concept of borders, which occurred where this did not create confusion at the level of existing national borders. On the one hand, the European context made borders more flexible, in that they now functioned as a means of communication. On the other, this new state of affairs blurred borders, reorganised the lives of the inhabitants and impacted on their contact with those across the borders. Thus the main feature that characterises ethnic borders in a context of reversed direction is that representations of such borders become more aggressive and conflict-oriented. 
In my view, the Pomaks (Tsibiridou 2000), a Slavonic-speaking ethnic group within the Muslim minority in Thrace, which was recognised by the Treaty of Lausanne in 1923, exemplify this phenomenon. The Muslim minority in western Thrace consists of three different ethnic groups (Turks, Pomaks, and Gypsies), the total number being, according to the Greek census of 2011, 116,000 (Christidis 1996: 136) $)^{6}$. Of course, estimates of the numbers of the Muslim population in Thrace depend on the aim of the demographic record in question (Aarbakke 2000: 35-40). The Muslim minority, as they were termed in accord with the Treaty of Lausanne of 1923, which laid down the borders between Greece and Turkey in their final form and which was signed after the military defeat of the Greeks in Asia Minor, was excepted from the exchange of Muslims and Christians who lived in Greece and Turkey respectively (Yildirim 2006: 45).

The Pomaks used to live, as many of them still do, in the mountains above Xanthi, one of the three prefectures of Thrace. ${ }^{7}$ Their chief source of income was the cultivation of tobacco, which gradually decreased, so that they were no longer able to support their families (Vernier 1981: 122-142). Thus after the Second World War some of them migrated to Athens within Greece and to Belgium (Madianou 2005: 527), a few shipped as members of the crew on cargo ships, whilst many of them moved down from the mountains either to the villages on the plain or to the town of Xanthi, where they married partners of Turkish origin. ${ }^{8}$ Their children were enrolled in minority schools. Turkey was responsible for these schools and provided teachers to teach the Turkish language and history. Furthermore, "from the early 1950s until 1967, the Greek state actively supported the linguistic Turkification of the local Muslim population, through compulsory minority education" (Antoniou 2005: 82).

The Pomaks are an exceptionally interesting example, if one wishes to broaden the link between external and internal borders, which are frequently not so invisible. Their own area was delimited by bares, as the Greek word is, that is, checkpoints, which controlled the flow of people entering the principal area occupied by the Pomaks (Markou 2010: 103). The presence of bares as a material border within a nation-state made clear the disadvantaged status of the Pomaks as an ethnic group. The bares identified the whole area with liminality and danger and was regarded as a polluted geography.

Unavoidably, then, an understanding of the identity of the Pomaks and of their position in the Muslim minority of Thrace can be gained when one applies Gramsci's concept of hegemony. This perspective "seems applicable to relations between Pomaks and Turks as well as to those between Pomaks and Greeks, where Pomaks are subordinated in both cases" (Demetriou 2004: 115). Tsibiridou uses the concept of the politics of place, to deal with the creation of sectioned-off areas in Thrace, divided into locations where "the lower ranges 
of society are regarded as possessing the exotic features of natives" (Tsibiridou 2005). She also uses it to deal with the role of the Turkish elite in the formation of these areas. Such ethnic areas are ranked hierarchically, depending on who is seen as the stronger party. In the past, however, the view focused more on the Muslim minority and its division, in relation to the Christian majority. In Western Thrace, in the view of the public discourse of the Greek administration that legitimised its arguments by reference to the Treaty of Lausanne, there was one landscape divided up into the world of Christians and the world of Muslims. The Pomaks were invisible, thanks to their geographical isolation, but also by reason of the indifference of the Greek state towards them. The Greek state had done nothing to improve standards of living or promote development in the area.

This is the result of the Treaty of Lausanne, which indeed imposed an institutionalised relationship with the Turkish state, nominated as a national centre for the Muslims (Troumbeta 2001: 33). Thus the Greek-Turkish borders on the Evros influenced the formation of internal borders between Muslims and Christians in western Thrace, which made no allowance for any internal differences within the minority itself. This is obvious in the fashion in which the Pomaks were defined. Poulton (1997: 84) labels them as Islamicised Slavs. The alternative and indiscriminating labels 'Muslim' and 'Turk' in the pre-war period did not cause tension. However, in the post-war period, "the way the minority was named became of crucial importance" (Tsitselikis 2007: 7). The Turkification of the Pomaks occurred after the Second World War, particularly during the 1970s, when a transnational Turkish identity evolved (Karakasidou 1995). This attracted the Pomaks and guaranteed their rights as citizens of the Greek state that had marginalised them. In addition, the Greek state was positively disposed to the Turkification of the Pomaks during the post-war period, given that they inhabited an area on the Greek-Bulgarian borders deemed 'dangerous'. The Bulgarians were at the time regarded as the enemy and the fear that Bulgaria had not relinquished its aim of altering the Greek-Bulgarian borders by demanding part of the Greek territory impacted upon the internal borders of the Pomaks. The gradual Turkification of the Pomaks was encouraged and the impression was given that the Pomak minority was homogeneous. Furthermore, the process of making a nation of the Muslim minority created an arena of conflict for Greece and Turkey. It was also an area in which origin myths evolved, so that they were absorbed into Greek or Turkish narratives. For the Greeks, the Pomaks were the descendants of the soldiers of Alexander the Great who had converted to Islam, whilst for the Turks the Pomaks were ancestors of Turks (Smith 1999: 57-95; Troumbeta 2001: 83). 
The issue of the identity of the Pomaks became an important national matter for Greece and Turkey, which attempted to put the term 'transnational Turkish identity' in clear form. For scholars, the identity of the Pomaks and the threepronged relationship among Greece, the Muslim minority, and Turkey formed an irresistible topic for research on the processes behind the formation of identities.

In the 1990s, Greek authorities reviewed their policy towards the Muslim minority in general and focused on the Pomaks in particular. In the mid-1990s, the Greek authorities changed the situation in Pomak areas, firstly by abolishing the bares, and secondly by introducing legislation to give all Muslims easier access to Greek universities. This approach was impossible until the 1990s, because of the educational conditions for the minority. After this legislation was passed, Muslims began to apply to Greek universities. All these changes were due to the appearance of human rights as a fundamental principle of the European Union and of other international bodies, such as the Council of Europe and the International Court of Human Rights (Aarbakke 2000). This became particularly the case during the 1990s and after the Greek state was obliged, as a member of the European Union, to adopt these new texts as part of its body of law.

The new European and international environment favours the expression of demands and of political identities. This arrangement makes clear the fluidity of the identity of the Pomaks in western Thrace. As a starting point for the broadening of the fluidity of their identity, we have the view, or rather, received opinion, that the life of an identity is dependent, to a great extent, upon its ability to offer protection, social status, and economic benefits for the members of a group (Eminov 2007: 1). For the Pomaks, Greece was to be identified with insecurity, poverty, lack of opportunities for social mobility, and the road barriers that symbolised all of this (Tsibiridou 1999: 163-182). As an ethnic group, they had a body of common experience that one would expect, which compelled them to adopt strategies of survival for dealing with their social environment, and of submission to whomever happened to exercise power. This occurred in the Bulgarian invasion during the Second World War (Demetriou 2004: 101). Thus Poulton's term for the Pomaks, 'Islamicised Slavs', ignores historical circumstances and fails to regard identities as malleable, which can be reformulated, manipulated, and changed. In fact, he regards it as fixed essence. In other words, both states, Greek and Turkey, attempted to show that Pomak identity was primordial, remaining indifferent to the fact that men, at a local level, choose their identity. The Pomaks were influenced by their experiences and views, and by their relations with the central administration or with other neighbouring ethnic groups (Bringa 1993: 70). The public discourse of both states, Greece and Turkey, clashes at the level of internal borders. Turkey 
attempts to legitimise the existence of the internal border in Greece, which has facilitated its function as a national centre for the Muslim, and so Turkish, minority. Greece attempts, unofficially, to link the Pomaks with a Greek descent, which would then cast doubt on their identity.

These two policies have caused cracks in the type of identity chosen by the Pomaks. A fair number have chosen a Turkish identity. This Turkish identity is particularly strong among Pomak academics and those ambitious to enter political life, the local administration, or to hold other positions.

Many Pomak scholars and intellectuals became members of the Turkish Union of Xanthi. A court case was fought over the name of the Union (Kyriakou 2009: 7), as to whether it should be the 'Muslim Union' or the 'Turkish Union', and the insistence of the members of the minority on the adjective 'Turkish' showed that Pomak scholars and intellectuals had been Turkified (Tsitselikis 2007: 8). The closer Greece was tied to the European Union, the more the minority demands for ethnic self-ascription increased. The Turkish Union of Xanthi is the most characteristic example of how the weakening of strict national borders is not necessarily correlated to any tendencies influencing ethnic boundaries within the nation-state. To sustain a symbolic issue related to how a minority is named, a fact that does not take into account social realities, turns a political matter into a human rights problem (Markou 2003: 43-55). That is, to change the name of a minority from 'Muslim' to 'Turkish' has a symbolic value only. In other words, this argument deals with such a process in terms of only superficial change. However, the renaming process involves borders and representations of otherness both inside and outside the Muslim minority. According to Bourdieu, all symbolic strategies are used by agents to "impose their vision of the division of the social world" (Bourdieu 1997 [1991]: 239).

Thus the predominance of the adjective 'Turkish' over 'Muslim' in how cultural associations and other societies define themselves could perhaps be regarded as a shifting of the border, in the sense that the inter-ethnic borders within the Muslim minority have lost their symbolic value as an emblem of differentiation. Instead, the use of the adjective 'Turkish' implies that the minority discourse illuminates the borderline between Christians and Muslims. The most important aspect lies in the change of the adjective. Thus the border has now been drawn between Greeks and Turks. In any case, Pomakness does not have any independent existence. It is a slippery identity, an area that is open to any expansion in relations of power, subordination, and national policies (Demetriou 2004: 100). This is clear in the most obvious fashion in the elections for the local administration and for the Greek parliament. The case of Gulbeyaz Karahasan is typical. She was a PASOK (Pan-Hellenic Socialist Movement Party) candidate for the 'super-prefecture' that included the pre- 
fectures of Drama, Kavala, and Xanthi, and a member of the Muslim minority descended from the Pomak villages around Xanthi.

The daughter of Muslim farmers, she was born in the village of Glavki, in the municipality of Myki, 28 years ago. The inhabitants of the village are $100 \%$ Muslim. Her father was a farmer and carpenter, in order to bring up three daughters. (Giannaka 2006)

This extract from an article repeatedly stresses her religious identity, which accords with the public discourse of the Greek state regarding this identity. Yet her village is one of the Pomak villages. Her candidacy provoked controversy and various extreme reactions. The decision of PASOK was regarded as an attempt to force to the surface the question of the Pomaks, while ignoring Turkey as a national centre for the Pomaks. Some political circles in Athens stressed that the Pomak origin of Ms Karahasan drew her away from the unchanging plans of Ankara and the Turkish Consulate (Kalliagopoulos 2006). In other words, the selection of Karahasan as a candidate showed how complicated the issue of the Pomaks was. Their identity thus became an arena for conflict, which was occasionally difficult to interpret for the uninitiated. The aim was control of the Pomaks and the matter of whether the fault line in Thrace would continue to divide the inhabitants into Christians and Muslims or would bring out new lines of division among the ethnic minorities of Thrace. Furthermore, the Karahasan affair revealed the existence of yet another important centre of power in the Pomak minority. This is the Turkish Minority of Western Thrace Advisory Committee, since Karahasan's candidacy required approval by the members of the Turkish minority. This set off a heated debate, since it was considered to be by extension the policy of the leaders of the minority and of Turkey, whose aim was to control the members of the minority that wielded power.

In addition to this, the candidacy of Karahasan and her life form a frame of reference for whatever is said to the effect that Pomak identity is fluid and labile. To deal with this dimension, Demetriou employs the example of two young Pomaks, Selim and Osman, who chose identities different from each other. The first "could be a Pomac Turk" and the second "could be considered a Pomak Greek" (Demetriou 2004: 101).

The case of Karahasan shows that identity is a more complicated and multilevel matter, to the point that Selim and Osman exist in the same person, as is the case with Karahasan and many other members of the minority of Pomak origin. The fluidity and multiplicity of their identity allow the Pomaks to adapt to various circumstances and use them to their advantage (Eminov 2007: 5). Karahasan is a member of the Turkish Union of Xanthi, of which the greater part of Pomak intellectuals who have studied in Turkey are members. 
Various ethnic groups usually adopt the identity of the dominant group when they share the same religion. This process facilitates survival strategies and social upward mobility. In the case of the Muslim minority of western Thrace, the ambitions of young academics and intellectuals for professional, social, and political progress are to be achieved only through the agency and in the context of the minority, which functions as another form of power, an alternative to the indifferent Greek state. "Turkishness is a hegemonic minority identity discourse" (Demetriou 2004: 101). Consequently, the Pomaks, after Turkish education at primary and secondary level and training at Turkish universities, have no choice other than to join 'Turkish' associations to indicate that they are Turkish and to map out their future, as their starting point, with the Muslim minority that struggles for recognition as Turkish. Besides, the elite of the minority disapprove of the use of the ethnic term 'Pomak', as it might revive the old inter-ethnic borderline within the minority. Thus the Muslim or Turkish Union of Xanthi, as well as all the other cultural and professional associations for members of the Muslim minority in Greek Thrace, functions as a symbolic space, in which "a play of differences" (Gupta \& Ferguson 1997: 17) and identities are shaped.

It was inevitable that Karahasan joined the Turkish Union, since public discourse regarding identity can develop "within seemingly solid classificatory boundaries" (Demetriou 2004: 100). This view is reinforced by a consideration of the reaction on the part of various elements in Greece, such as the media, various associations, and websites. These brought into the living rooms of Greek households across the country the matter of the Muslim minority and its ethnic groups. If we leave aside the various conspiracy theories that were articulated, the participation of Karahasan made clear her intention to move into a new area of activity, where her Pomak descent has great importance for the understanding of the fluidity of her identity, even if she declares herself to be Turkish. This is indeed a case of doubt being cast upon the solid classificatory boundaries in the definition of identities.

\section{POMAK PUBLIC DISCOURSE}

During the 2000s the public discourse of Pomaks who wished to be recognised as Greeks was formulated. The Pomak Cultural Association of Xanthi, established in 2007, returned to the issue of Pomak identity and the inter-ethnic borderline. The members of the association wrote in their declaration: 
Most of our fellow citizens, either because of ignorance or intention, persist in identifying Islam with the Turks. We are Pomaks, deeply rooted in the land of Thrace, and our destiny is unbreakably connected with that of this land. We want to live in this area, preserving our language, belief, and our ancestors' customs, in order to hand them down to our children. ${ }^{9}$

This extract is clear. It displays the opinion of those who have composed it that there is an inter-ethnic borderline within the Muslim minority, whose existence is questioned by minority authorities and even by a great number of Pomaks who have chosen the Turkish identity. Light is cast on all the discourse over the name of the Pomak ethnic group by the view of Barth, who maintains that what is important in such cases is the "ethnic boundary that defines the group rather than the cultural stuff that it encloses" (Barth 1969: 15). The Pomaks choose a minority consciousness, albeit rejecting any attempt to define them as members of the Turkish minority. Their association, the newspaper Natprash, and the website zaglisa.gr, are expressions of the other element that chooses the Greek identity, in that they accept the mythological story regarding their descent from the soldiers of Alexander the Great. Journalist Karahotza, one of the leaders of the group who wish to maintain their Pomak identity, states, "They simply want to be known as Pomaks, because this is a fact, and want to proclaim their Greek consciousness" (Karahotza 2009). This is the first time that a demand for the Pomak identity has appeared, along with terms defining the identity, and the myth of descent that has been formulated by a group of Greek academics (Seyppel 1989: 42). Doubt is thereby cast on the internal borders of the Muslim minority. This group of Pomaks are now demanding education via use of the Greek language and have sent a letter to the Prime Minister. ${ }^{10}$ This action directly casts doubt on the validity of the Treaty of Lausanne, that is, on the acceptance of Turkey as their national centre.

The whole attitude of minority authorities and minority elite towards the possibility of restoring the internal border is condensed in a public debate that occurred in the village of Echinos, which was the capital of the Pomakochoria area in the Xanthi Mountains. Riots broke out, protests being lodged about an actress who insulted the beliefs of the local inhabitants by entering a mosque in a supposedly immodest dress. I cannot myself say whether the person in question did, or did not, behave in this fashion. Even if the matter had its origins in such unacceptable behaviour, I have the impression that the main point lies in how this case then developed. It was an opportunity for minority authorities and those who wished to regard the minority as a Turkish ethnic group to formulate the matter in a collective manner. Their reaction managed to end up, functioning as a ritual expression, making clear their desire that it be taken for granted that there are no Pomaks and that no intra-ethnic border exists. 
In general, the more Greece comes to adopt European legislation, the more the Muslim minority - at least minority authorities and elites - increase their demands for self-definition, which means allowing their cultural associations to be renamed. There is no doubt that this situation arises from a long-term policy implemented by the Greek state over the second half of the 20th century. Thus over all this period there was complete correspondence between an inflexible representation of the national borderline and the marginalised minority. Both of them occupied a liminal space regarded as polluted and dangerous. The newly-established European environment put the spotlight on the minority as it drew attention to the new state of affairs. A number of Pomaks have ended up defining themselves as Turks, after the process of Turkification that occurred during the period when the Greek authorities thrust the Pomaks to the margins of the state, believing this to be the only solution. The state regarded the members of this minority as liminal, a fact that justified their marginalisation, and the lower status accorded them as citizens of the Greek state. What emerges from the public debate over where the ethnic borderlines of the Muslim minority in Thrace are to be drawn consists of two main issues. The first one relates to a ritual held in the area of the Alevi Pomaks, on the Sitsek plateau, each August (Tsibiridou 2005: 79). This is a summer feast, which in recent decades has been transformed into a ritual for sanctifying the minority unification as a whole and at the same time for reaffirming the fact that self-definition as Turks prevails over particular ethnic names, i.e. Pomaks and Roma. The main activities of this rite consist of wrestling contests on the one hand and of the gathering of politicians and delegates of cultural and other groups on the other. Everything that occurs at this feast, official or otherwise, including the plateau itself, the participants, the wrestling, the symbols, the music, the flags, the discussions, the politicians and their speeches, constitutes the essence of this discourse, which focuses on the practice and the objectification of a sense of belonging.

Wrestlers from Turkey, mostly from Edirne (Adrianoupolis) area, come and compete. However, the most important aspects of the event lie in how this rite is contextualised by its organisers.

The Turks of western Thrace revived on the Sitsek Plateau (Chilia being the name in Greek) the traditional wrestling organised by our people living in the Evros region. Each year visitors from our mother country came over. The Turks who arrived at the Sitsek Plateau from across western Thrace watched traditional wrestling and the dance groups of the Turkish Union of Xanthi, the Union of Komotini Turkish Youth and the Association of the Southern Evros and Goniko. ${ }^{11}$ 
The website emphasises the identity of those who participated in the festival. Among them were the Consul General of Turkey in Komotini, Thrace, the mufti (Muslim expert on the law of Koran), mayors, and delegates of associations and societies. At the same time it stresses the absence of 'Greeks' and Muslims as members of Parliament in Greece.

This text makes very clear what is taking place on the Sitsek Plateau. This article upbraids Muslim politicians who avoided taking part in this annual event, and attributes their behaviour to the possibility that perhaps they took it for just a rite. This makes it clear how this event is contextualised by the organisers. Obviously the controversial point is not the ritual dimension of the whole meeting. This is unquestionable, however one regards the event. Thus the main point of this public discourse is to be associated with what it focuses on. In other words, we appear to have conflicting views concerning the aim of the ritual. The rite in the past used to be a ritual to encourage reproduction for the Bektashi religious community in Thrace. Gradually this content was transmuted and different material was introduced. It provided the appropriate formula for reproducing the new collectivity and identity. Consequently, the main point of these events has been to reaffirm that the only border that exists is the one between Turks and Greeks.

\section{CONCLUSIONS}

Borders epitomise historical routes, national ambitions, conflicts and rivalries, cultural similarities and dissimilarities. All these are expressed in a national or ethnic mythology which, if illuminated in an appropriate way, can offer much regarding representations, thoughts, emotions, and the aims of neighbouring populations.

The border between Greece and Turkey, after the two nation-states had been established, and especially during the 20 th century, imposed a policy that brought about a spatial reorganisation of the Greek territory, which involved the division and marginalisation of Thrace. This was responsible for its stigmatisation as a 'polluted area', so to speak. The absorption of Greece into the European Union changed this view of the border with Turkey, which was under complete control even as late as the beginning of the 1990s. Closer relations between Greece and the European Union influenced the representation of the border and improved relations with Turkey. This was reflected in the relations of both Greece and Turkey with the Muslim minority of Thrace.

Although the reorganisation of space continues, increasing transnational migration from Asia and Africa, particularly with the background of the finan- 
cial crisis that hit Greece at the end of the 2000s, this process is responsible for bringing about a change in the meaning of the borders and of Thrace itself. The erection of the fence that functions as a wall on the Greek-Turkish border brings out into the open the need to redefine the terms of discussion on concepts such as borders, identity, Europe, and minorities. Above all, the fence is a challenge to reorder Greek-Turkish relations and the relationships between the visible border, i.e. the Evros region, and the unseen borders, i.e. the ethnic groups of the Muslim minority of Thrace.

\section{NOTES}

1 The word 'septemvriana' refers to everything the Turks did against the Greek minority in Istanbul in September 1955. This included destruction and burning of 1,004 houses, 4,348 shops, 27 pharmacies and laboratories, 21 factories, 110 restaurants, a number of cafes and hotels, 73 churches, 26 schools, 5 sports clubs, and 2 cemeteries (Alexandris 1992: 259).

2 One of the songs which constitute the circle of the songs of Constantinople/Istanbul, depicting the fall of the city under the power of the Ottomans in 1453 and encouraging Greeks that sometime in the future the city will become Greek again.

${ }^{3}$ Herzfeld called disemia such a fundamental concept (Herzfeld 1989: 95-122).

${ }^{4}$ Here we have a practical application of the concept of the 'politics of place' (Appadurai 1986).

5 The phrase 'liminal space' recalls the expression 'territorial space' (Van Gennep 1965: 15).

6 "This profoundly religious minority of 100,000 - composed of approximately 70,000 Muslims of Turkish ethnic origin, 35,000 Pomaks (slavophone Muslims) and 5000 Muslims of Romany ethnic origin" (Oran 2003: 98).

7 The area of Pomaks is located in the Rodope Range, which is the border with Bulgaria, where over 250,000 Pomaks, called Bulgarian Mohammedans, live (Poulton 1991).

8 The same occurs in the case of the Pomaks who migrate to Komotini, the regional capital of western Thrace (Demetriou 2004: 101).

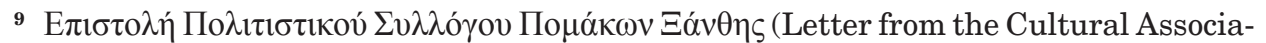
tion of Pomaks, prefecture of Xanthi, western Thrace). March 4, 2009. Available at https://voukino.wordpress.com/2009/03/04/pomakoi/, last accessed on October 5, 2015.

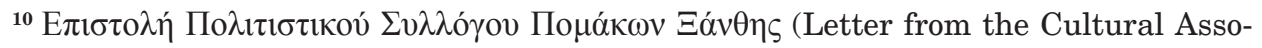

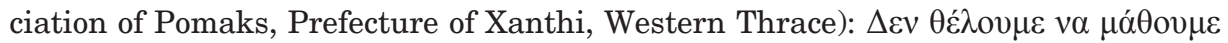

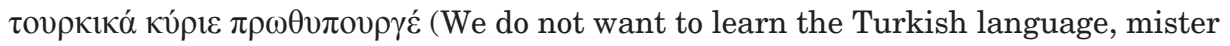
Prime Minister). Available at http://infognomonpolitics.blogspot.com.ee/2010/03/blogpost_6559.html, last accessed on November 6, 2015. 


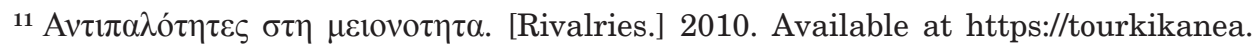
wordpress.com/2010/08/06/secek-2/, last accessed on November 6, 2015.

\section{REFERENCES}

Aarbakke, Vemund 2000. The Muslim Minority of Greek Thrace. Diss. (PhD Thesis). University of Bergen. Unpublished.

Akçam Taner 2004. From Empire to Republic: Turkish Nationalism and the Armenian Genocide. London \& New York: Zed Books.

Alexandris, Alexis 1992. The Greek Minority of Istanbul and Greek-Turkish Relations, 1918-1974. Athens: Centre for Asia Minor Studies.

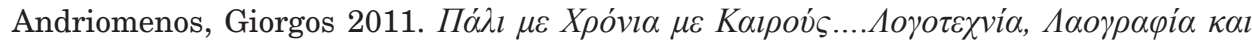

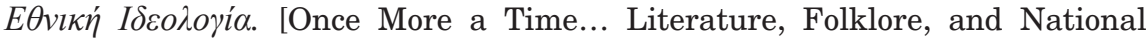
Ideology.] Athens: I. Sideris.

Antoniou, Dimitris 2005. Western Thracian Muslims in Athens: From Economic Migration to Religious Organization. Balkanologie, Vol. 9, No. 1-2, pp. 79-101. Available at http://balkanologie.revues.org/579, last accessed on October 6, 2015.

Appadurai, Arjun 1986. Theory in Anthropology: Center and Periphery. Comparative Studies in Society and History, Vol. 28, No. 2, pp. 356-361. http://dx.doi. org/10.1017/S0010417500013906.

Ardener, Edwin 1989. Language, Ethnicity and Population. In: M. Chapman (ed.) The Voice of Prophecy and Other Essays. Oxford: Blackwell, pp. 65-71.

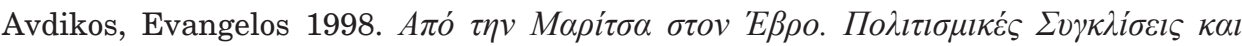

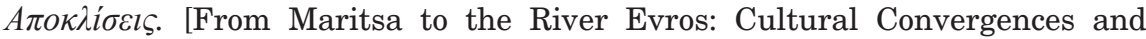
Divergences.] Alexandroupolis: Municipality of Tyhero.

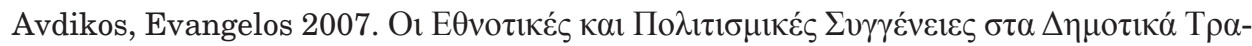

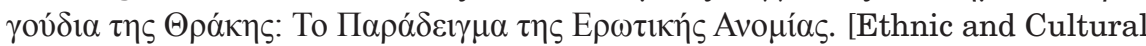
Affinities and Contrasts in the Folk Songs of Greece: The Example of Erotic

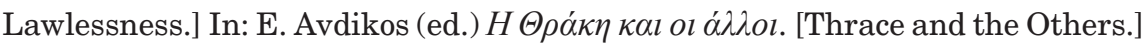
Athens: Odysseas, pp. 104-121.

Barth, Fredrik 1969. Introduction. In: F. Barth (ed.) Ethnic Groups and Boundaries: The Social Organization of Culture Difference. London: Allen and Unwin, pp. 9-38.

Bourdieu, Pierre 1997 [1991]. Language and Symbolic Power. Cambridge, UK: Polity Press.

Bringa, Tone R. 1993. Nationality Categories, National Identification and Identity Formation in "Multinational" Bosnia. The Anthropology of East Europe Review, Vol. 11, No. 1-2, pp. 80-89. Available at https://scholarworks.iu.edu/journals/ index.php/aeer/article/view/591, last accessed on October 6, 2015.

Brunnbauer, Ulf 1999. Diverging (Hi-)Stories: The Contested Identity of the Bulgarian Pomaks. Ethnologia Balkanica, Vol. 3, pp. 35-50.

Certeau, Michel de 1980. L'Invention du Quotidien. Paris: UGE.

Cohen, Abner 1974. Two-Dimensional Man: An Essay on the Anthropology of Power and Symbolism in Complex Society. London: Routledge \& Kegan Paul. 
Christidis, Yorgos 1996. The Muslim Minority in Greece. In: Gerd Nonneman \& Tim Niblock \& Bogdan Szajkowski (eds.) Muslim Communities in the New Europe. Berkshire: Ithaca Press, pp. 153-166.

Demetriou, Olga 2004. Prioritizing 'Ethnicities': The Uncertainty of Pomak-ness in the Urban Greek Rhodoppe. Ethnic and Racial Studies, Vol. 27, No.1, pp. 95-119. DOI: 10.1080/0141987032000147959.

Demirözü, Damla 2008. The Greek-Turkish Rapprochement of 1930 and the Repercussions of the Ankara Convention in Turkey. Journal of Islamic Studies, Vol. 19, No. 3, pp. 309-324. DOI:10.1093/jis/etn003.

Ellison, Ralph 1952. Invisible Man. New York: Vintage International.

Eminov, Ali 2007. Social Construction of Identities: Pomaks in Bulgaria. Journal of Ethnopolitics and Minority Issues in Europe, Vol. 2, pp. 1-25. Available at http:// www.isn.ethz.ch/Digital-Library/Publications/Detail/?lang=en\&id=115615, last accessed on October 6, 2015.

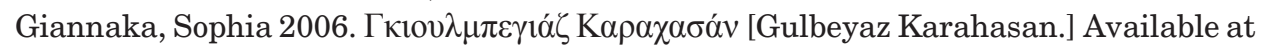
http://www.tovima.gr/politics/article/?aid=173197, last accessed on November 13, 2015.

Gielis, Ruben 2009. Borders Make the Difference: Migrant Transnationalism as a Border Experience. Tijdschrift voor Economische en Sociale Geografie, Vol. 100, No. 5, pp. 598-609. http://dx.doi.org/10.1111/j.1467-9663.2009.00572.x.

Görög-Karady, Veronika 1992. Ethnic Stereotypes and Folklore: The Jew in Hungarian Oral Literature. In: Reimund Kvideland (ed.) Folklore Processed: In Honour of Lauri Honko on his 60th Birthday, 6th March 1992. Helsinki: Suomalaisen Kirjallissuuden Seura, pp. 114-126.

Gupta, Akhil \& Ferguson, James 1997. Culture, Power, Place: Ethnography at the End of an Era. In: A. Gupta and J. Ferguson (eds.) Culture, Power, Place: Explorations in Critical Anthropology. Durham \& London: Duke University Press, pp. 1-29.

Fisher Onar, Nora \& Özgüneş, Meriç 2010. How Deep a Transformation? Europeanization of Greek and Turkish Minority Policies. International Journal on Minority and Group Rights, Vol. 17, No. 1, pp. 111-136. DOI: 10.1163/157181110X12595859 744240.

Herzfeld, Michael 1986. Ours Once More: Folklore, Ideology and the Making of Modern Greece. New York: Pella Publishing Company.

Herzfeld, Michael 1989 [1987]. Anthropology through the Looking-Glass: Critical Ethnography in the Margins of Europe. Cambridge, UK: Cambridge University Press.

Hirschon, Renée 2008. History's Long Shadow: The Lausanne Treaty and Contemporary Greco-Turkish Relations. In: Othon Anastasakis \& Kalypso Nicolaidis \& Kerem Öktem (eds.) In the Long Shadow of Europe: Greeks and Turks in the Era of Postnationalism. Leiden \& Boston: Martinus Nijhoff, pp. 73-94. Available at https://www.anthro.ox.ac.uk/fileadmin/images/staff/Associates/15--history_s_ long_shadow_proofs.pdf, last accessed on October 6, 2015.

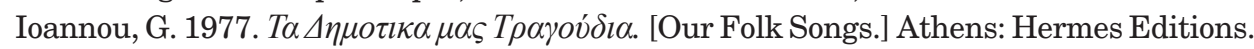




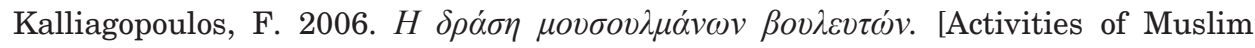
Members of Greek Parliament.] May 13. Available at http://www.kathimerini. gr/250838/article/epikairothta/politikh/h-drash-moysoylmanwn-voyleytwn, last accessed on November 13, 2015.

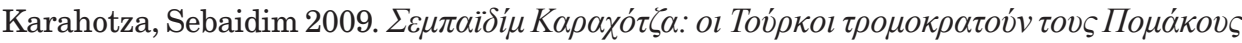

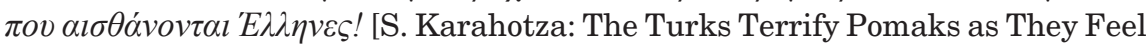
Greeks!] Available at http://proxeneio-stop.org/?s=\%CE\%B1\%CE\%B9\%CF\%83\% $\mathrm{CE} \% \mathrm{~B} 8 \% \mathrm{CE} \% \mathrm{AC} \% \mathrm{CE} \% \mathrm{BD} \% \mathrm{CE} \% \mathrm{BF} \% \mathrm{CE} \% \mathrm{BD} \% \mathrm{CF} \% 84 \% \mathrm{CE} \% \mathrm{~B} 1 \% \mathrm{CE} \% \mathrm{~B} 9++\%$ $\mathrm{CE} \% \mathrm{AD} \% \mathrm{CE} \% \mathrm{BB} \% \mathrm{CE} \% \mathrm{BB} \% \mathrm{CE} \% \mathrm{~B} 7 \% \mathrm{CE} \% \mathrm{BD} \% \mathrm{CE} \% \mathrm{~B} 5 \% \mathrm{CF} \% 82$, last accessed on November 13, 2015.

Karakasidou, Anastasia 1995. Vestiges of the Ottoman Past: Muslims under Siege in Contemporary Greek Thrace. Cultural Survival Quarterly, Vol. 19, No. 2, pp. 71-75. Available at http://www.culturalsurvival.org/publications/culturalsurvival-quarterly/192-summer-1995-nationalism-eastern-europe, last accessed on October 6, 2015.

Kyriakou, Nikolas 2009. Minority Participation in Public Life: The Case of Greece. Journal on Ethnopolitics and Minority Issues in Europe, Vol. 2, pp. 1-18. Available at http://www.isn.ethz.ch/Digital-Library/Publications/Detail/?ots591=0c54e3b31e9c-be1e-2c24-a6a8c7060233\&lng=en\&id=115480, last accessed on November 20, 2015.

Laube, Lena \& Roos, Christof 2010. A "Border for the People"? Narratives on Changing Eastern Borders in Finland and Austria. Journal of Borderlands Studies, Vol. 25, Nos. 3-4, pp. 31-49. DOI:10.1080/08865655.2010.9695770.

Levi-Strauss, Claude 1966. The Savage Mind. London: Weidenfeld and Nicholson.

Linke, Uli 1990. Folklore, Anthropology, and the Government of Social Life. Comparative Studies in Society and History, Vol. 32, No. 1, pp. 117-148. DOI: http://dx.doi. org/10.1017/S0010417500016352.

Madianou, Mirca 2005. Contested Communicative Spaces: Rethinking Identities, Boundaries and the Role of the Media among Turkish Speakers in Greece. Journal of Ethnic and Migration Studies, Vol. 31, No. 3, pp. 521-541. http:// dx.doi.org/10.1080/13691830500058760.

Markou, Katerina 2003. La Terminologie Adoptée à propos des Musulmans de Thrace Grecque. Mésogeios, Vol. 20-21, pp. 43-55.

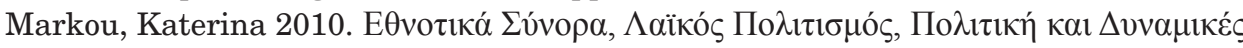

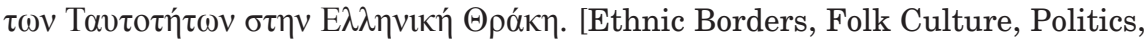

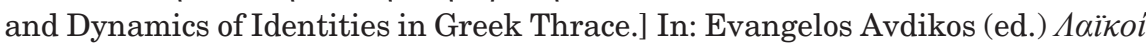

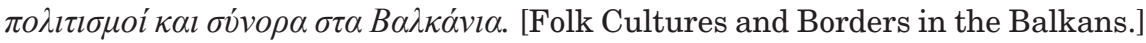
Athens: Pedio, pp. 97-118.

Memisoglu, Fulya 2007. The European Union's Minority Rights Policy and Its Impact on the Development of Minority Rights Protection in Greece. Available at http://www. lse.ac.uk/europeanInstitute/research/hellenicObservatory/pdf/3rd_Symposium/ PAPERS/MEMISOGLOU_FULYA.pdf, last accessed on September 23, 2015. 
Narayan, Kirin 1993. How Native Is a "Native" Anthropologist? American Anthropologist, Vol. 95, No. 3, pp. 671-686. http://dx.doi.org/10.1525/aa.1993.95.3.02a00070.

Ngunjiri, Faith Wambura \& Hernandez, Kathy-Ann C. \& Chang, Heewon 2010. Living Autoethnography: Connecting Life and Research. Journal of Research Practice, Vol. 6, No. 1, pp. 1-17. Available at http://jrp.icaap.org/index.php/jrp/article/ view/241, last accessed on September 22, 2015.

Oran, Baskin 2003. The Story of Those Who Stayed: Lessons from Articles 1 and 2 of the 1923 Convention. In: Renée Hirschon (ed.) Crossing the Aegean: An Appraisal of the 1923 Compulsory Population Exchange between Greece and Turkey. Oxford: Berghahn, pp. 97-116.

Paredes, Américo 1995 [1993]. The Problem of Identity in a Changing Culture: Popular Expressions of Culture Conflict along the Lower Rio Grande Border. In: R. Bauman (ed.) Folklore and Culture on the Texas-Mexican Border. Austin: University of Texas Press, pp. 19-48.

Politis, N. G. 1918. Croyances Populaires sur le Retablissement de la Nation Hellenique. Revue de Gréce, Vol. 1, No. 1, pp. 151-170.

Pollis, Adamantia 1992. Greek National Identity: Religious Minorities, Rights, and European Norms. Journal of Modern Greek Studies, Vol. 10, No. 2, pp. 171-196. http://dx.doi.org/10.1353/mgs.2010.0193.

Poulton, Hugh 1991. The Balkans: Minorities and States in Conflict. London: Minority Rights Publications.

Poulton, Hugh 1997. Changing Notions of National Identity among Muslims in Thrace and Macedonia: Turks, Pomaks and Roma. In: H. Poulton \& S. Taji-Farouki (eds.) Muslim Identity and the Balkan State. London: Hurst and Company, pp. 82-102.

Prokkola, Eeva-Kaisa 2008. Border Narratives at Work: Theatrical Smuggling and the Politics of Commemoration. Geopolitics, Vol. 13, No. 4, pp. 657-675. http://dx.doi. org/10.1080/14650040802275495.

Rizas, Sotiris 2009. Managing a Conflict between Allies: United States Policy towards Greece and Turkey in Relation to the Aegean Dispute, 1974-76. Cold War in the Aegean. Cold War History, Vol. 9, No. 3, pp. 367-387. DOI:10.1080/14682740802170883.

Smith, Anthony D. 1999. Myths and Memories of the Nation. Oxford: Oxford University Press.

Strüver, Anke 2003. Presenting Representations: On the Analysis of Narratives and Images along the Dutch-German Border. In: E. Berg \& H. Van Houtum (eds.) Routing Borders Between Territories, Discourses and Practices. Aldershot, GB: Ashgate, pp. 161-176.

Seyppel, Tatjana 1989. Pomaks in Northeastern Greece: An Endangered Balkan Population. Journal Muslim Minority Affairs, Vol. 10, No. 1, pp. 41-49. DOI:10.1080/02666958908716100.

Stuckey, Leigh 2009. Narrating the Greco-Turkish Population Exchange: Stories about Belonging and Otherness in the Nation. Diss. (MA Thesis). Duke University, Department of Cultural Anthropology. Available at http://dukespace.lib.duke. edu/dspace/handle/10161/1282, last accessed on October 7, 2015. 
Theodossopoulos, Dimitrios 2006. Introduction: The 'Turks' in the Imagination of the 'Greeks'. South European Society \& Politics, Vol. 11, No. 1, pp. 1-32. DOI:10.1080/13608740500470299.

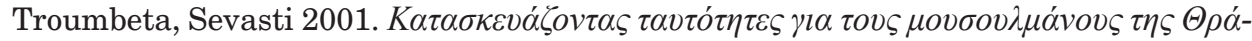
$\kappa \eta \varsigma$. [Constructing Identities for the Muslims in Thrace: The Pomak and Roma Issue.] Athens: Kritiki.

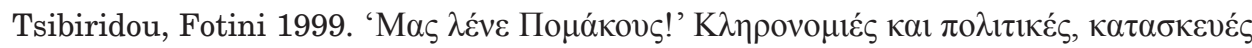

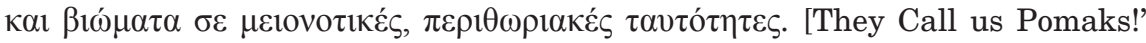
Legacies and Experiences in the Identities of Marginalised Minorities.] Mví $\mu \omega v$ [Mnimon], Vol. 21, pp. 163-182. http://dx.doi.org/10.12681/mnimon.789.

Tsibiridou, Fotini 2000. Les Pomak dans la Thrace Grecque: Discours Ethnique et Practiques Socioculturelles. Paris: L'Harmattan.

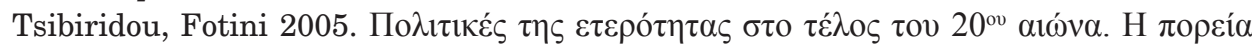

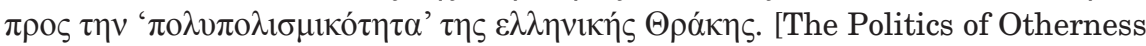
at the End of the 20th Century: The Path towards Multiculturalism in Greek

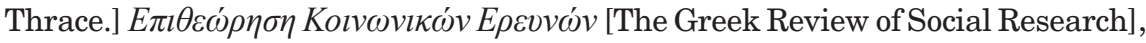
Vol. 118, pp. 59-93.

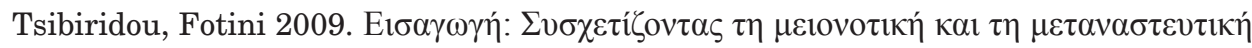
$\varepsilon \mu \pi \varepsilon i p i ́ \alpha$. [Introduction: Linking the Minority and Migrant Experiences.] In: F. Tsi-

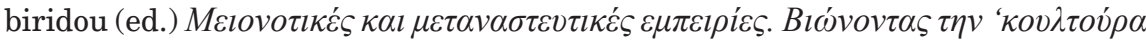

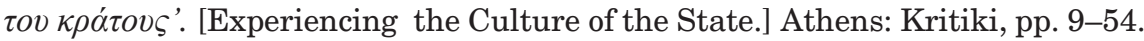

Tsitselikis, Konstantinos 2007. The Pending Modernisation of Islam in Greece: From Millet to Minority Status. Südosteuropa, Vol. 4, pp. 354-372. Available at http://www.ceeol.com/aspx/issuedetails.aspx?issueid=185158aa-f4fa-429e-92b8c2a19dd788ef\&articleid=d1d7f028-5705-4f10-b6f9-890a3effab81\#ad1d7f0285705-4f10-b6f9-890a3effab81, last accessed on October 7, 2015.

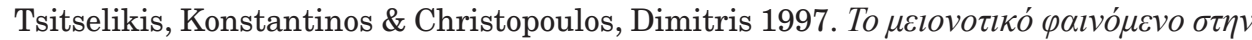
$E \lambda \lambda \alpha \dot{\delta} \alpha$. [The Minority Phenomenon in Greece.] Athens: Kritiki.

Turner, Victor 1967. The Forest of Symbols: Aspects of Ndembu Ritual. Ithaca \& London: Cornel University Press.

Van Gennep, Arnold 1965 [1960]. The Rites of Passage. London: Routledge and Kegan Paul.

Van Houtum, Henk 2005. The Geopolitics of Borders and Boundaries. Geopolitics, Vol. 10, No. 4, pp. 672-679. DOI:10.1080/14650040500318522.

Vernier, Bernard 1981. Représentation Mythique du monde et Domination Masculine chez les Pomaques Grecs. The Greek Review of Social Research: Special Volume, pp. 22-142. Available at http://www.grsr.gr/index.php/ekke/article/view/571/1965, last accessed on October 7, 2015.

Vryonis, Speros 2005. The Mechanism of Catastrophe: The Turkish Pogrom of September 6-7, 1955, and the Destruction of the Greek Community of Istanbul. New York: greekworks.com.

Yiakoumaki, Vassiliki 2003. The Nation as "Acquired Taste": On Greekness, Consumption of Food Heritage, and the Making of the New Europe. Diss. (PhD Thesis), The New School, New York. Unpublished. 
Yildirim, Onur 2006. The 1923 Population Exchange, Refugees and National Historiographies in Greece and Turkey. East European Quarterly, Vol. 40, No. 1, pp. 45-70. Available at http://www.academia.edu/3242406/_Historiography_of_ the_Turco-Greek_Exchange_of_Populations_, last accessed on October 8, 2015.

Zayas, Alfred de 2007. The Istanbul Pogrom of 6-7 September 1955 in the Light of International Law. Genocide Studies and Prevention, Vol. 2, No. 2, pp. 137-154. Available at http://scholarcommons.usf.edu/gsp/vol2/iss2/4/, last accessed on October 6, 2015. 